\title{
A study on women's awareness related to consumer practices in Jamnagar
}

\section{Bhavna D. Ranch}

Author for correspondence Bhavna D. Ranch

Department of Home Science, Bhavan's Shri A.K.Doshi Mahila College, Jamnagar (Gujarat) India Email : ranchbhavnad@ gmail.com

Received: 06.06.2019; Accepted: 29.11.2019

ABSTRACT : Consumers need protection from different kinds of exploitation by unfair trade practices in the market place at India and everywhere. In this situation Consumer Protection Act, 1986 provide better protection of the interests of consumers if consumers are aware of their rights and Consumer Protection Act. Here, consumer means any person who buys any goods or hire or avail any services and awareness means understanding of or information about a subject that you get by experience or study, either known by one person. So a study conducted "A study on women's awareness related to consumer practices in Jamnagar". There is some correlation between educational qualification and consumer awareness about Consumer Protection Act. There is some correlation between occupation and consumer awareness about Consumer Protection Act. Over all age wise, education wise and occupation wise more than 59.6 percentage women had medium level of awareness about Consumer Protection Act. For honest people self-regulation works well and legislation is superfluous. For dishonest people legislation is not always very powerful deterrent. The existing laws which have been framed to protect and safeguard the interest of the consumers at large, are not being effectively implemented and enforced to achieve the objectives of the Consumer Protection Act. In short, legislation is not cure-all but consumer awareness makes them more powerful.

KEY WORDS: Consumer awareness, Consumer act, Women

- HOW TO CITE THIS PAPER : Ranch, Bhavna D. (2019). A study on women's awareness related to consumer practices in Jamnagar. Asian J. Home Sci., 14 (2) : 468-472, DOI: 10.15740/HAS/AJHS/14.2/ 468-472. Copyright@ 2019: Hind Agri-Horticultural Society. 